\title{
Toetsing in de opleiding tot gynaecoloog
}

\author{
F. Scheele, J.I. Puyenbroek, B. Wolf, M.F. Schutte, M.I Schade
}

\section{Samenvatting}

Toetsing van gynaecologen in opleiding (AGIO's) geschiedt tot op heden traditioneel door niet in didactiek geschoolde opleiders op basis van inschattingen van kennis, vaardigheden en communicatie en het uitblijven van ongelukken tijdens het werk. Met de komst van het medisch opleidingscontinuüm, de toenemende roep om efficiëntere opleiding en een maatschappelijke behoefte aan transparantie en kwaliteitsborging bij het afleveren van medische specialisten wordt het belangrijk om een onderwijskundig onderbouwd toetsbeleid te gaan invoeren. Of er werkelijk snelle veranderingen zullen komen hangt vooral af van de vraag of de beroepsgroep daar nu al het nut van inziet. Pas wanneer de beroepsgroep de impact van de toetsing op de ontwikkeling van de AGIO groot genoeg zal schatten en ten tweede de noodzaak voldoende zal voelen om gedegen besluiten te nemen over geschiktheid van AGIO's zal er veel in toetsing geïnesteerd gaan worden.

Kwaliteitscriteria als betrouwbaarheid en validiteit spelen een rol bij de keuze van toetsvormen, en het denken in 'rollen' die de gynaecoloog moet bekleden helpt bij het beschrijven van wat moet worden getoetst. De CanMEDS 2000-rollen lijken valide voor de Nederlandse gynaecologische praktijk. Gepleit wordt voor een competentiegerichte toetsing met een geschikte mix van toetsmethoden. Het gaat hier om schriftelijke toetsen van kennis en begrip, simulatietoetsen van praktijksituaties en de toetsing van het functioneren in de medische praktijk. In een portfolio, waarin de toetsresultaten overzichtelijk gebundeld worden, zullen door de AGIO zelfreflecties worden vastgelegd op diens ontwikkeling in de CanMEDS-rollen. Bovendien worden in de portfolio taken voor de komende periode vastgelegd.

Voor de ontwikkeling van een dergelijk toetsbeleid is een goede samenwerking nodig tussen onderwijskundigen en gynaecologen. Voor de implementatie ervan zijn projectmatig denkende verandermanagers nodig.

Een goed toetsbeleid kan een grote impact hebben op de effectiviteit van de opleiding en kan dienen als verbeterde kwaliteitsgarantie voor afgeleverde gynaecologen. (Scheele F, Puyenbroek JI, Wolf B, Schutte MF, Schade MI. Toetsing in de opleiding tot gynaecoloog. Tijdschrift voor Medisch Onderwijs 2004;23(1):40-50.)

\section{Inleiding}

Er is in de Nederlandse Vereniging van Obstetrie en Gynaecologie (NVOG) een discussie opgelaaid over het curriculum voor gynaecologische assistent-geneeskundigen in opleiding (AGIO's). Onder andere gestimuleerd door het Centraal College Medische Specialismen (CCMS) wordt nu gewerkt aan een modulaire opleidingsstructuur. Modules van de 6-jarige opleiding zullen meestal 6 maanden gaan duren. De modulaire structuur is nog niet geheel uitgekristalliseerd. Het plan is AGIO's te laten beginnen met de opleiding in een niet-academisch opleidingsziekenhuis zoals nu ook meestal gebeurt. $\mathrm{Na}$ twee jaren gaat de AGIO dan voor enkele jaren naar een academisch centrum om in het laatste opleidingsjaar weer niet-academisch te werken. Er wordt, om een idee te 
geven, voor de eerste 2 jaren van de opleiding gewerkt aan 4 modules. Eerst een module van een half jaar verloskunde gericht op de basale competenties voor het functioneren op verloskamers, op een kraamafdeling en op een verloskunde polikliniek voor zwangere patiënten met een laag risico. Vervolgens komt er een module gericht op basale competenties voor het doen van gynaecologische behandelingen, zowel op de operatiekamers als op de afdeling. De derde module is gericht op competenties die nodig zijn voor het functioneren op de polikliniek gynaecologie. De vierde module richt zich weer op complexere gynaecologische behandelingen. Met duidelijke eindtermen voor iedere module wordt zo de moeilijkheidsgraad van het werken tijdens de opleiding volgens een afgesproken pad opgebouwd. De opleider weet wat er geboden moet worden aan opleidingsmomenten, de AGIO weet wat er geleerd moet worden. De modulaire structuur maakt het beter mogelijk om op korte termijn vast te stellen of leerdoelen ook echt gehaald worden. Momenteel is er vaak geen afgesproken structuur in de opleiding, wat kan leiden tot het onjuist ingezet worden van AGIO's op de werkvloer (voornamelijk productie) en het onopgemerkt oplopen van achterstanden bij het vergaren van competenties (geen transparantie).

Er bestaat bij menigeen de overtuiging dat de geplande herstructurering van de opleiding tot gynaecoloog in modules hand in hand moet gaan met een herziening van het toetsbeleid. Het huidige toetsbeleid behelst 3-maandelijkse, door een logboek ondersteunde, globale beoordelingen door het opleiderteam en een jaarlijkse zelfbeoordeling door middel van een schriftelijke voortgangstoets. Opleiders zijn meestal niet didactisch geschoold. De methodiek van het toetsen van competenties en van het geven van feedback is niet uniform en wordt meer gestuurd door locale tradities dan door onderwijskundige inzichten.

De discussie over herstructurering van de specialistische opleidingen en daarmee van het toetsbeleid leeft ook internationaal. In Denemarken bijvoorbeeld is een door de overheid betaald project ten behoeve van de specialistische opleidingen op papier in een vergevorderd stadium. ${ }^{1}$

$\mathrm{Om}$ in ons land de discussie over de toetsing van onze AGIO's in brede kring de kans te geven, wordt in het nu volgende stuk de laatste meningsvorming binnen de NVOG over toetsbeleid en toetsing in grote lijnen op schrift gesteld. Achtereenvolgens komen aan de orde: de veranderende context die vraagt om aanpassing van het toetsbeleid, een overzicht van aspecten die bij toetsing van AGIO's van belang zijn, een globaal overzicht van toetsvormen en een voorstel van toepassing van die toetsvormen in de opleiding tot gynaecoloog, en ten slotte enkele aspecten van de implementatie van een nieuw toetssysteem.

\section{Nieuw toetsbeleid in een veranderde context}

Een eerste reden om aan te voeren waarom toetsing van AGIO's belangrijk is, is het komende medische opleidingscontinuüm. ${ }^{2}$ Momenteel putten wij onze AGIO's voornamelijk uit artsen die nog niet in opleiding zijn, maar die wel in goede zin opvallen op de werkvloer. De beoordeling in de eerste twee jaren van de opleiding is daarmee een hérbeoordeling geworden die in de praktijk vaak goed uitvalt. In de toekomst, wanneer het medische opleidingscontinuüm ingericht is, vindt het beoordelingsproces wat tot definitieve selectie moet leiden alleen tijdens de opleiding van de AGIO plaats en niet al deels in de fase daarvoor. De toetsing in de eerste twee jaren van de op- 
leiding tot gynaecoloog, waarin besloten moet worden of iemand geschikt is, wordt daardoor nog belangrijker.

Een tweede reden is de maatschappelijke roep om een efficiëntere opleiding. Het toetsbeleid is de drijvende kracht achter de activiteiten van de student. ${ }^{3}$ Met toetsing wordt aangegeven welke competenties op welk niveau verwacht worden. Daarmee is dus zowel de opleiding met haar opleiders als de AGIO te sturen. Adequate toetsing geeft de mogelijkheid om tot een individueel leertraject te komen. Er kan dan flexibel gereageerd worden op snellere en langzame AGIO's.

Een derde reden is de maatschappelijke roep om kwaliteitsborging en transparantie. Wij kunnen geen gynaecologen afleveren die marginaal getoetst zijn. Wij moeten kwaliteit kunnen aantonen, zowel van de afgeleverde gynaecologen als van het eigen systeem van opleiden. Daarom zullen we moeten gaan werken volgens een helder geformuleerde visie op onderwijs en toetsing met een kwaliteitszorgsysteem als borging.

\section{Toetsing en toetsbeleid: aspecten die bij toetsing van AGIO's van belang zijn}

\section{Het nut van toetsing}

Vanuit een adequaat toetsbeleid wordt duidelijk waarom, hoe en wat de opleiders willen bereiken en met welke middelen. Het toetsbeleid bestaat uit een deel inhoud en kwaliteit, een deel regelgeving, een deel organisatie en een deel financiën. Van der Vleuten heeft een utiliteitsformule geformuleerd waarin de parameters die het nut van een toetsbeleid bepalen een plaats krijgen. ${ }^{4}$ Het nut van toetsbeleid $=$ betrouwbaarheid $\times$ validiteit $\times$ onderwijsconsequenties $($ impact $) \times$ acceptabiliteit $\times$ kosten. Een verstandig toetsbeleid kan voor een betrouwbare, valide en zo kosteneffectief mogelijke toetsing zorgen. Vragen waar het bij de gynaecologen in de discussie over nut vooral op aan zal gaan komen, zijn ten eerste of de impact van de toetsing op de ontwikkeling van de AGIO groot genoeg gevonden wordt en ten tweede hoe sterk de noodzaak gevoeld wordt om gedegen besluiten te nemen over geschiktheid van AGIO's. De acceptabiliteit hangt in dit geval voornamelijk af van de impact. Voor een betrouwbare en valide toetsing kan zeker in de eerste twee jaren van de opleiding een flinke inspanning nodig blijken waarvoor een breed draagvlak vereist is.

\section{Kwaliteitscriteria van toetsing}

\section{Summatieve en formatieve doelen}

Met toetsing kan men verschillende doelen nastreven. Men kan selectie nastreven en dus door toetsing een AGIO laten slagen of zakken. Dat wordt summatief toetsen genoemd. De summatieve toets voor onze AGIO's wordt op last van de Medisch Specialisten Registratie Commissie (MSRC) voor het einde van het tweede opleidingsjaar afgerond. Summatief toetsen stelt hoge eisen aan de kwaliteit van de toetsing, want een afgewezen AGIO kan de toetsing juridisch aanvechten.

Een volgend doel van toetsing ligt in de diagnostische waarde ervan en in de sturing op het leerproces van de individuele AGIO. Dit wordt de ontwikkelingsgerichte ofwel formatieve toetsing genoemd. Formatieve toetsing blijft gedurende de hele opleiding van belang. "Students learn what you inspect, not what you expect" (uitspraak van Hart, 1998). Voor het toetsbeleid van de NVOG willen we enige nadruk leggen op summatieve toetsing in de eerste twee jaren van de opleiding en louter op formatieve toetsing in de resterende vier jaren. Tevens is het voor de opleiding van belang dat de evaluaties van de toetsing ook gebruikt worden voor de verbetering van de opleiding en haar opleiders. 


\section{Betrouwbaarheid}

Het toetsbeleid zal, zoals hierboven gesteld werd, vooral tijdens de eerste twee jaren van de opleiding van een hoge kwaliteit moeten zijn. Om iemand terecht af te wijzen, maar ook om iemand terecht door te laten (maatschappelijk gezien een heel verantwoordelijke daad) moet er aan criteria van betrouwbare en valide toetsing voldaan zijn. Met betrouwbaarheid wordt de reproduceerbaarheid van de toetsing bedoeld. Wanneer een AGIO die afgewezen is, opnieuw via het zelfde toetssysteem zou worden beoordeeld, zou die dan opnieuw als onvoldoende herkend worden?

De betrouwbaarheid van een toetssysteem en de toetsen daarbinnen is op verschillende manieren te verbeteren. Ten eerste door te toetsen op basis van veel verschillende casus. Eén schriftelijk examen aan het einde van het tweede jaar aan de hand van één of enkele casus is niet acceptabel op grond van het feit dat veel medische competentie inhoudsspecifiek is gebleken. ${ }^{5}$ Dat houdt bijvoorbeeld in dat het 'klinische probleemoplossen' geen algemene vaardigheid is, maar gekoppeld is aan kennis van ziektebeelden en aan ervaring. Wanneer er dus met te weinig verschillende casus wordt getoetst, is de kans te hoog dat er net casuïstiek wordt voorgelegd die in de bekwaamheidsontwikkeling van de AGIO onderbelicht is gebleven. De kans is dan relatief groot dat bij het voorleggen van meer casus de algemene medische competentie van de AGIO veel gunstiger blijkt uit te vallen. Met het toetsen van meerdere casus wordt de deviatie vanaf het juiste beoordelingsresultaat ten gevolge van inhoudsspecificiteit van medische competentie verminderd.

Een tweede manier om betrouwbaarheid te verbeteren is de toetsing door meerdere beoordelaars. Wanneer alle toetsen door dezelfde opleider worden verricht, bestaat het risico dat er te veel persoonlijke aversie (of adoratie) in de beoordeling door gaat klinken, of dat de AGIO een 'havik' treft die altijd buitengewoon streng oordeelt of een 'duif' die altijd buitengewoon mild is. Het gebruik van meerdere beoordelaars middelt deze beoordelaarvariatie uit. Stevige protocollen en transparante beoordelingslijsten voor praktijktoetsen helpen hier ook.

Een potentiële valkuil bij het summatief toetsen in de opleiding van AGIO's V\&G is dat de opleiders tegelijkertijd in de rol van coach/leraar én in de rol van beoordelaar worden geplaatst. De opleider beoordeelt dus ook het resultaat van zijn/haar eigen werk en dat kan de betrouwbaarheid ongunstig beïnvloeden.

Een derde manier om de betrouwbaarheid gunstig te beïnvloeden is het gebruik van meerdere toetsmomenten en -methoden. Deze oplossing is krachtig gebleken om een breed perspectief te krijgen op de ontwikkeling van de lerende en tegelijk de valkuilen van onbetrouwbaarheid en gebrekkige validiteit te ontlopen: de zogeheten 'methodenmix'.

\section{Validiteit}

Met alleen betrouwbaarheid komen we er nog niet. Het toetssysteem moet ook valide zijn. Dat betekent dat wat je toetst ook datgene is wat je wilt meten. Als de toets moet aangeven of de AGIO een goede dokter is op de werkvloer, dan is een schriftelijke kennistoets niet valide. Of om een ander voorbeeld te geven, als een AGIO op een operatiesimulator een begaafde operateur blijkt, dan is dat nog niet automatisch een valide meting voor diens functioneren in een operatieteam. Toetsing wint aan validiteit wanneer die plaats vindt in de authentieke context. Dat betekent dat toetsing van een AGIO vooral plaats moet vinden op de werkvloer waar de te beoordelen competenties getoond worden. Het is lastig om competenties op de werkvloer 
(hoge validiteit) betrouwbaar te beoordelen. Een goede mix van toetsmethoden en toetsmomenten kan toch resulteren in een relatief geldig beeld van de AGIO in zijn/ haar competentieontwikkeling.

\section{Product- en procestoetsing}

De toetsing zal zich niet alleen richten op het bekwaamheidsniveau van de AGIO (product). De toetsing zal ook gericht moeten zijn op de ontwikkeling (proces) van de AGIO tot een volwaardig medisch specialist. Het focussen op het persoonlijke leerproces en de zelfsturing door de AGIO wordt van groot belang geacht om het levenslang leren te initiëren.

Competenties als richtsnoer: het denken in rollen

Voor het beschrijven van medische competenties wordt tegenwoordig gebruik gemaakt van rollen. Iedere 'heilige plaats' van het onderwijs (Ottawa, Maastricht, Dundee, Groningen) bedenkt zijn eigen rollen, maar in de kern van de zaak gaat het om de methodiek van beschrijven van de vereiste competenties. Het CCMS heeft gekozen voor de onlangs in Canada ontwikkelde zeven CanMEDS 2000-rollen, te weten: medical expert, communicator, collaborator, manager, scholar, health advocate en professional. ${ }^{6}$ Deze rollen zijn in Canada naar boven gekomen via een procedure waarbij maatschappelijke groeperingen hun mening gaven. Voor het beschrijven van de medische competenties van de gynaecoloog in een raamplan zullen we ook van deze CanMEDS 2000rollen gebruik maken.

\section{Toetsvormen: een mix van minder en meer praktijk}

Om betrouwbaar en valide te toetsen is het belangrijk goed te kiezen welke mix van toetsvormen het beste gebruikt kunnen worden. Enkele bij de ideeën van de
NVOG over toetsbeleid voor AGIO's aansluitende methodieken worden hier in het kort besproken.

\section{Kennis, begrip en specialistische expertise}

Voor betrouwbare toetsing van kennis, begrip en specialistische expertise zijn meerkeuzevragen bruikbaar. De gynaecologische AGIO wordt jaarlijks onderworpen aan een schriftelijke voortgangstoets met 'juist-onjuist-weet niet' keuze. Als variant daarvan is onlangs de 'Script Concordance test' ontwikkeld die beter aansluit op het hogere expertiseniveau van de medische specialist en die zich leent voor het summatief toetsen in de modules. ${ }^{7}$

\section{Simulatie van de praktijk}

Waar kennis en begrip aanwezig zijn, is een logische aanvulling de toetsing met simulaties. ${ }^{8}$ Voor gynaecologen bekende voorbeelden zijn verloskundige fantoomexamens en het tonen van knoopvaardigheden op tafelpoten en specifiekere opzetjes die de kwaliteit van de knopen beter meten. Een ander voorbeeld van een simulatie-examen is de calamiteitoefening. Bij een calamiteitoefening wordt de AGIO gebeld voor een acuut patiëntprobleem, zoals een eclampsie of een ernstige fluxus. Op een scorelijst worden enkele globale oordelen gegeven over het tonen van kennis van zaken en bekwaamheid tot handelen. Welke acute onderwerpen getoetst kunnen worden is tevoren aan de AGIO bekend.

Voor dergelijke simulatie-examens zijn specifieke maar handzame beoordelingsformulieren nodig. In de endoscopische chirurgie zijn 'virtual reality trainers' met toenemende mogelijkheden tot toetsing voorhanden. Naast toetsing bij medischtechnische vaardigheden ligt het voor de hand ook simulaties in te zetten bij de toetsing van gespreksvaardigheden, 
samenwerkingsvaardigheden en andere aspecten van professioneel gedrag. ${ }^{9}$

\section{Het functioneren in de medische praktijk}

Als in de simulaties voldoende vaardigheden aanwezig blijken te zijn, komt de toetsing van het functioneren in de medische praktijk in beeld. Deze toetsing toetst pas echt waar het om gaat en zal dus prioriteit moeten krijgen. Het gaat dan om gestructureerde observaties en documentaties van de AGIO in al zijn verschillende (CanMEDS) rollen. ${ }^{10}$ Een praktisch voorbeeld van een praktijkobservatie is de 360 graden beoordeling. ${ }^{11}$ De AGIO deelt op het einde van de module 10 identieke beoordelingslijsten uit aan verschillende teamleden. Medische specialisten, een AGIO, een co-assistent, enkele verpleegkundigen, enkele verloskundigen en secretaresses zijn geschikt voor het 360 graden beoordelen. De gekozen teamleden vullen de lijsten in en zonder dat de AGIO de inhoud daarvan ziet, gaan de lijsten naar de opleider die er een gemiddelde beoordeling van maakt. De gemiddelde versie wordt met de AGIO besproken. De ter beoordeling gevraagde items (vrij naar Whitehouse) zijn:

- Blijk van gemotiveerdheid.

- Communicatie.

- Teamwork.

- Professioneel gedrag.

- Stressbestendigheid.

- Initiatief.

Een ander voorbeeld van een praktijktoets is de 'mini-CEX' (mini-clinical evaluation exercise). ${ }^{12}$ Voor deze toets die per module meermalen plaats kan vinden, gaat een lid van het opleiderteam bijvoorbeeld een half uur op de polikliniek bij het spreekuur meekijken en vult het globale scoreformulier in. Kennis is hierbij moeilijk te scoren, maar een indruk over com- municatie, management en professioneel gedrag zijn wel degelijk haalbaar.

De indruk van het opleiderteam blijft als praktijktoets om reden van validiteit van groot belang en voor de gynaecologische AGIO's is een 3-maandelijkse 'beoordeling door het opleiderteam' gangbaar. De verslaglegging geschiedt gestructureerd op een scorelijst. De betrouwbaarheid van deze beoordeling door de opleiders kan wel eens gunstig worden beïnvloed wanneer het opleiderteam eerst kennis neemt van de resultaten van andere toetsvormen.

Een andere vorm van praktijkobservatie is die van het bijgehouden 'logboek' waarin verrichtingen en ervaringen te tellen zijn. Hierbij kan het gaan om zaken die bij de ontwikkeling van de rol van medisch expert passen, zoals aantallen bevallingen of operaties. Het kan ook gaan om communicatieve verrichtingen, zoals 'slecht nieuws gesprekken'. In het logboek is ook plaats voor 'critically appraised topics'. Klinische vraagstukken worden door de AGIO met evidence based medicine opgelost. Korte verslagen van die exercities komen in het logboek. Samen met bijdragen aan protocollen, wetenschappelijk onderzoek en publicaties kunnen deze onderwerpen uit het logboek een indruk geven over de rol van wetenschapper in de praktijk. Onderwijsverrichtingen, waarbij ook aandacht voor onderwijskundige aspecten kan worden gevraagd, geven een indruk over de rol van leraar. De rol van 'gezondheidsvoorlichter' kan aandacht krijgen door een in het logboek verslagen door de AGIO georganiseerde informatieavond voor zwangere vrouwen of een variant daarvan aangedragen door de AGIO. De rol van professional kan in het logboek een plaats krijgen door de beschrijving van een medische misser of klacht, in het licht van professioneel gedrag. Hierdoor wordt de 
AGIO gedwongen zich te verdiepen in de vraag wat bedoeld wordt met professioneel gedrag en waar codes gelden.

De validiteit van deze toetsvormen in de praktijk is hoog, de betrouwbaarheid relatief laag. Het toetsbeleid geeft aan hoe dit op te vangen, zodat het totaalbeeld van de zich ontwikkelende AGIO wel valide en tevens betrouwbaar te noemen is.

\section{Het portfolio als 'overall toets'}

De bundeling in een portfolio van de documentatie die verkregen wordt via alle toetsmomenten wordt uitgevoerd onder verantwoordelijkheid van de AGIO. De AGIO laat in de portfolio zien dat hij zich ontwikkelt volgens de gestelde doelen. Periodieke schriftelijke zelfreflectie hoort daarbij. ${ }^{13}$ De periodieke zelfreflectie wordt voorzien van feedback door een opleider en er wordt in overleg met de AGIO een taakstelling voor de komende periode aan gekoppeld (reflectief leren). Een praktische vormgeving hiervan is de schriftelijke koppeling van eindtermen aan patiëntencasuïstiek, waarbij de AGIO door het toetsende karakter ervan gemotiveerd wordt om zich te verdiepen in de eindtermen en leerdoelen van een module. Belangrijk is dat een dergelijke toetsing niet leidt tot veel papierwerk. De instructie aan de AGIO moet helder zijn: 'Toon aan dat het eigen leerproces gespiegeld wordt aan eindtermen.' Een tweede praktische vormgeving is de driemaandelijkse sterkte-zwakte-analyse over de 7 CanMEDS-rollen en taakstelling. De instructie aan de AGIO is om het reflectief leren bondig op schrift te tonen, aangevuld door een samenvatting van de feedback uit het opleiderteam.

Voor toetsing is de portfolio dus te beschouwen als een door de AGIO beheerd ontwikkelingsdossier waarin op basis van de CanMEDS 2000-rollen gestructureerde documentatie verzameld is en voorzien van eigen reflecties en die van significante anderen (figuur 1). Met deze portfolio kan de AGIO aan een daartoe in het leven geroepen portfoliocommissie bewijzen dat hij over voldoende medische competentie beschikt voor de opleidingsfase waarin hij verkeert. De commissie geeft een waardering aan het portfolio als geheel en geeft adviezen. Na 1 jaar en na 2 jaren wordt beslist over zakken of slagen. De portfoliocommissie wordt voorzien van een examenreglement dat aangeeft hoe de procedures verlopen, met welke beoordelingsmethoden er gewerkt wordt, hoe om

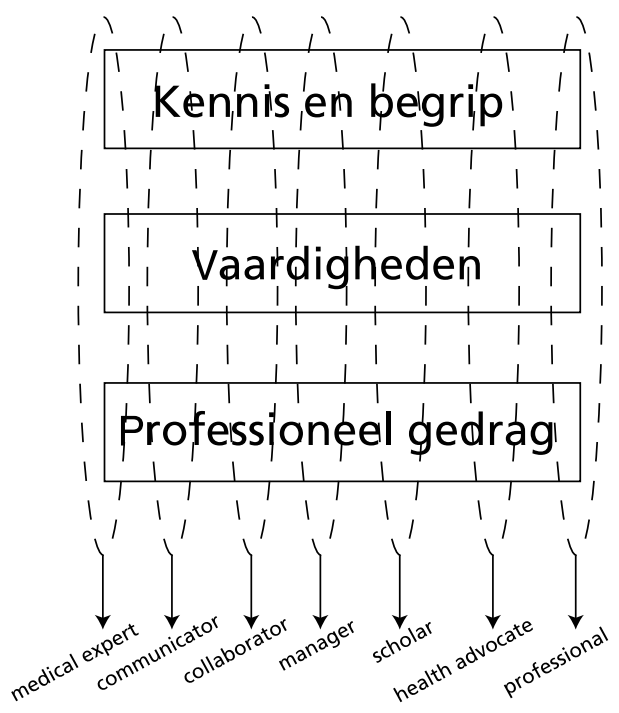

Figuur 1. De deelcompetities die als (CanMEDS 2000) rollen worden beschreven, zijn geweven uit kennisaspecten, vaardigheden en professioneel gedrag. De competentie is door integratie van kennis, vaardigheden en professioneel gedrag sterker dan alleen de som der delen. Tijdens de opleiding worden er verschillende competentieniveau's bereikt die in de vorm van autorisaties naar de praktijk vertaald kunnen worden. Momenteel liggen de in het NVOG-logboek gebruikte autorisaties selectief in de rol van medisch expert. Het ligt voor de hand dat ook het gebied van communicatie, maar ook in andere rollen autorisaties wenselijk zijn. 
te gaan met compensatie, twijfelgevallen et cetera. De kwaliteitszorg hierbij dient adequaat uitgewerkt te zijn, onder andere om beroepsprocedures te voorkomen.

\section{Implementatie van portfolio: zijn we er klaar voor?}

Dat de implementatie van een portfolio in de gynaecologische beroepsgroep een grote onderneming zal zijn wordt gesuggereerd door een enquête die gehouden werd onder AGIO's gynaecologie over het gebruik van het huidige simpele logboek. ${ }^{14}$ Dit logboek geeft overzicht waar het gaat om aantallen uitgevoerde procedures, scholing en wetenschappelijke productie. Het logboek vraagt niet om zelfreflectie of taakstelling met een overzichtelijk tijdpad. Een derde van de AGIO's vult het logboek niet in. Meer dan een derde van de AGIO's gelooft dat de opleider het logboek niet zinnig vindt en bij slechts de helft van de AGIO's komt het logboek bij beoordelingsgesprekken ter tafel. Meer dan $80 \%$ van de AGIO's sprak zich uit voor herziening van het logboek in het kader van de komende opleidingsherstructurering. Een aantal AGIO's schreef als opmerking dat een herzien logboek niet meer tijd mocht gaan kosten. Er werd geconcludeerd dat de grote inzet die nodig is voor bewijsvoering van groei in de verschillende rollen van de gynaecoloog en voor zelfreflectie nodig is, schokkend kan worden ervaren binnen het opleidingssysteem voor gynaecologen. Een kritische factor zal de scholing zijn in het gebruik van portfolio, zowel van de AGIO als van de opleider.

\section{Specifiekere ideeën over de invulling van het toetsbeleid}

Hoe gaat de toetsing er dan uit zien?

De voorgestelde herstructurering van de opleiding tot gynaecoloog gaat van modu- les uit die ieder 6 maanden in beslag nemen. In de eerste 2 opleidingsjaren komen, zoals hiervoor beschreven, achtereenvolgens de modules verloskunde, gynaecologie 1, polikliniek en gynaecologie 2 aan bod. Iedere module zal een eigen toetsinhoud hebben. Het toetsbeleid volgt met de nodige creativiteit een ordening volgens de te ontwikkelen CanMEDS-rollen. De toetsvormen zullen in de verschillende modules per rol een in grote lijnen repeterend sjabloon volgen.

Een voorbeeld van toetsing in de module verloskunde wordt gegeven in tabel 1 . Het moge duidelijk zijn dat het sjabloon van dit voor de module verloskunde voorgestelde toetsbeleid op alle andere modules kan worden gebruikt.

\section{Hoe nu verder: enkele aspecten van implementatie}

\section{Kritische succesfactoren}

Bovenstaande voorstellen zijn globaal van aard en waar het op de uitwerking aankomt, ligt er nog veel werk. Bij de nadere uitwerking en invoering van het toetsbeleid van de NVOG is het onze keuze om klinisch werkende gynaecologen aan het roer te houden. Die roergangers moeten wel goed ondersteund blijven door onderwijskundigen en door 'last but not least': projectmatig denkende verandermanagers.

De zeven sleutelfactoren in dit veranderproces zijn: 15

1. Analyse:

Waarom zouden we een nieuw toetsbeleid invoeren? Wat kunnen we behouden, wat gaan we vernieuwen, met welk doel, wat zijn onze resources, et cetera?

2. Communicatie/informatie:

Alle betrokkenen (dus opleiders en AGIO's) worden blijvend geïnformeerd en geraadpleegd over het nieuwe toets- 
Tabel 1. De module verloskunde met toetsvormen waarmee de verschillende CanMEDS-rollen beoordeeld gaan worden.

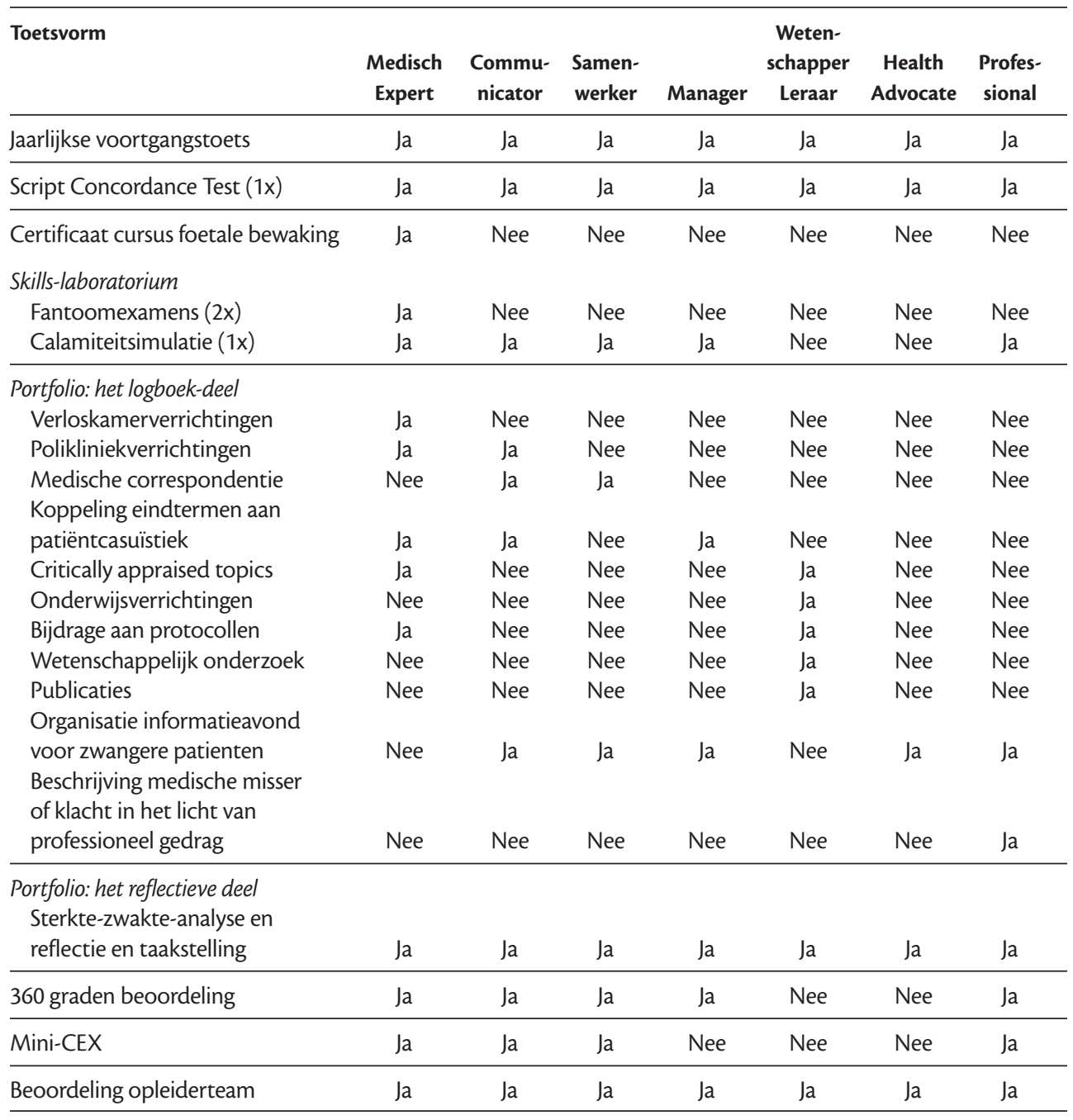

De tabel is soms wat kunstmatig absoluut. Alle toetsmomenten worden door de AGIO overzichtelijk gebundeld. Het resultaat daarvan noemen we het portfolio. Het wordt gebruikt voor zelftoetsing, voor leergesprekken met de opleider en ten behoeve van summatieve toetsing door de portfoliocommissie.

beleid. Onderlinge verwachtingen en taken worden steeds helder gecommuniceerd en bijgesteld.

3. Strategie:

De NVOG draagt het nieuwe beleid uit en stimuleert en faciliteert de opleiders ('walk your talk'). Er wordt gewerkt met pilots en met het uitwisselen van 'good practices'. Er is bewustzijn van gewenning en begrip voor weerstand. De NVOG kent haar eigen deskundigheden, gebruikt deze en raadpleegt zo nodig externe experts. 
4. Tolerantie voor verschillen in startsnelheid:

De NVOG tolereert verschillen in het opstarten met nieuw toetsbeleid en nieuwe toetsvormen en procedures. Zij neemt weerstanden zeer serieus om commitment te creëren. Zij geeft echter ook grenzen aan. Op eenmaal genomen besluiten komt men niet meer terug.

5. Snelheidsverschillen tijdens het veranderproces:

Niet alle opleiders doen direct mee; dat wil niet zeggen dat zij niet zouden willen. Vaker zijn het langzame starters.

6. Scouting:

Scouts zijn personen die beoordelen of we op de goede weg zijn met de veranderingen. Scouts leveren een belangrijke bijdrage aan succesvolle veranderingen. Het is wel belangrijk dat scouts een plek hebben in de veranderorganisatie en erkende en gewaardeerde collega's zijn.

7. Timing van de verandering:

Het starten van een verandering naar nieuwe toetsing moet op een geschikt moment worden ingezet; niet te vroeg en niet te laat. Misschien is het nu het goede moment?

\section{Wetenschappelijke onderbouwing gaande de toetsing}

Er zal een wetenschappelijk onderzoeksprogramma gekoppeld moeten worden aan het nieuwe toetsbeleid voor de validatie van de gebruikte toetsmethoden, de procedures daaromheen en de bijbehorende kwaliteitszorg. Zijn de resultaten overeenkomstig het gekozen beleid? Wat moet er anders en hoe dit aan te pakken?

\section{Scholing van opleiders en AGIO's}

Een intensief toetsbeleid vraagt om continue scholing van opleiders en AGIO's. De scholing moet aanleren om de voordelen van toetsing (zie boven) uit te buiten. Bovendien kunnen dan valkuilen als het verzanden in papierwerk worden voorkomen. Hier valt nog veel meer over te zeggen. Maar dat valt buiten het blikveld van dit artikel.

\section{Concluderend}

Toetsing is onlosmakelijk verbonden met verantwoord, efficiënt en transparant opleiden. In grote lijnen lijkt het duidelijk hoe we een goed toetsbeleid kunnen creëren. De NVOG staat nu voor een belangrijke keuze: pakken we door?

\section{Dankbetuiging}

Met dank aan Cees van der Vleuten en Albert Scherpbier voor de opbouwende commentaren op de eerste versie.

\section{Literatuur}

1. Ringsted C, Ostergaard D, Scherpbier A. Embracing the new paradigm of assessment in residency training: an assessment programme for first-year residency training in anaesthesiology. Med Teach 2003;25:54-62.

2. Meijboom-de Jong B, Schmit Jongbloed LJ, Willemsen MC, editors. De arts van straks - een nieuw medisch opleidingscontinuüm. Utrecht: KNMG/DMW-VSNU/VAZ/NVZ/LCVV; oktober 2002.

3. Cohen-Schotanus J. Student assessment and examination rules. Med Teach 1999; 21(3):318-21.

4. Vleuten CPM van der. Toetsing van medische competentie. In: Metz JCM, Scherpbier AJJA, Vleuten CPM van der, editors. Medisch onderwijs in de praktijk. Assen: Van Gorcum; 1995. p. 152-164.

5. Schmidt HG, Norman GR, Boshuizen HPA. A cognitive perspective on medical expertise: theory and implications. Acad Med 1990;65:611-21.

6. CanMEDS 2000 project. Skills for the new millennium: report of the societal needs working group. Ottawa; september 1996. http//rcpsc.medical. org/english/publications/canmed_e.html.

7. Charlin B, Roy L, Brailovsky C, Vleuten $\mathrm{C}$ van der. The Script Concordance test: a tool to assess the reflective clincian. Teach Learn Med 2000;12:18995.

8. Miller GE. The assessment of clinical skills/competence/performance. Acad Med 1990; 65(suppl): S63-7.

9. Projectteam Consilium Abeundi. Professioneel gedrag. Onderwijs, toetsing, begeleiding en regel- 
geving. Utrecht: Vereniging van Universiteiten (VSNU); 2000.

10. Wragg A, Wade W, Fuller G, Cowan G, Mills P. Assessing the performance of specialist registrars. Clin Med 2003;3:131-4.

11. Whitehouse A, Walzman M, Wall D. Pilot study of $360^{\circ}$ assessment of personal skills to inform record of in training assessments of senior house officers. Hosp Med 2002;63:172-5.

12. Norcini JJ, Blank LL, Arnold GK, Kimball HR. The mini-CEX (clinical evaluation exercise): a preliminary investigation. Ann Intern Med 1995;123:795-9.

13. Friedman Ben David M, Davis MH, Harden RM, Howie PW, Ker J, Pippard MJ. AMEE Medical Education Guide No 24: Portfolio's as a method of student assessment. Med Teach 2001;23(6):1-24.

14. Mahesh S, Sijtsma K, Scheele F, Wolf B, Schoot JThM van der. Het gynaecologisch logboek voor arts-assistenten: kansen voor een port folio? Programma NVMO congres 2003. p. 34.

15. Sweiker U. Seven success factors of organisational change. Warwick; 1995.
De auteurs:

Dr. F. Scheele is gynaecoloog in het Sint Lucas Andreas Ziekenhuis te Amsterdam en projectleider van de lopende herstructurering van de opleiding tot gynaecoloog.

Dr. J.I. Puyenbroek is werkzaam als gynaecoloog in het Sint Lucas Andreas Ziekenhuis te Amsterdam.

Dr. B. Wolf is werkzaam als pediater in het Sint Lucas Andreas Ziekenhuis te Amsterdam.

Dr. M.F. Schutte is gynaecoloog in het OLVG te Amsterdam en voorzitter van de NVOG.

Mw. drs. M.I. Schade is senior beleidsmedewerker bij het onderwijsbureau van het VUMC.

Correspondentieadres:

Dr. F. Scheele, gynaecoloog, Sint Lucas Andreas Ziekenhuis, Jan Tooropstraat 164, 1061AE Amsterdam, fedde@scheele.demon.nl.

\section{Summary}

Traditionally, trainees in postgraduate specialty training in Obstetrics and Gynaecology have been assessed by gynaecologists with no formal didactic training. It was considered sufficient proof of a trainee's competence when no work-related 'accidents' occurred and the trainee was seen to have adequate knowledge, clinical skills and communication skills. The advent of the medical education continuum and increasing societal demands with respect to transparency and quality assurance regarding specialty training are strong incentives to strive for educationally sound assessment strategies. The Dutch Society of Gynaecologists will have to be convinced of the need for and the potential benefits from such changes before a formal assessment programme can be implemented.

The effectiveness of assessment depends on quality criteria including reliability and validity. The seven physician roles developed in the Canadian Medical Education Directions for Specialists (CanMEDS) 2000 project may be a useful guideline in describing the competencies to be tested. In this article a case is made for competency-based assessment combining different approaches, such as written knowledge tests, objective structured clinical examinations and performance assessment in daily practice. The tests' results will be collected in a portfolio, together with reports of the trainees' self-reflection on their progress in the physician roles.

It is important that gynaecologists and educationalists should collaborate in designing an assessment programme. Project managers who are experts in the management of change will also have a crucial role in successful implementation.

An adequate and acceptable assessment programme will improve the quality, transparency and effectiveness of postgraduate training in Obstetrics and Gynaecology. (Scheele F, Puyenbroek JI, Wolf B, Schutte MF, Schade MI. Assessment of specialist registrars in gynaecology and obstetrics. Dutch Journal of Medical Education 2004;23(1):40-50.) 